\title{
Glazed balconies and their influence on the temperature reduction factor during the heating season
}

\author{
Magdalena Grudzińska ${ }^{*}$ \\ ${ }^{1}$ Lublin University of Technology, Faculty of Civil Engineering and Architecture, st. Nadbystrzycka 38, 20-618 Lublin, Poland
}

\begin{abstract}
Glazed buffer spaces have an important influence on the energy performance of buildings, especially in the case of dwellings located in multi-family buildings. The ability to utilize solar radiation during the heating season can be assessed with the use of the temperature reduction factor, expressing the relative temperature rise in the solar space above the outside air temperature. The paper is based on the results of the internal temperature monitoring in dwellings with glazed balconies of different envelope construction and airtightness. The dwellings were located in buildings in Lublin and Zamość, cities in the eastern part of Poland. The measurements took place from July 2017 until September 2018, and the temperature was recorded with the use of iButton sensors. The measurement results were supplemented with the weather data coming from the database of the Polish Institute of Meteorology and Water Management. Thanks to the collected data it was possible to calculate the temperature reduction factor during the subsequent months of the heating season, and to check its relationship with the factors such as the balconies' orientation, envelope construction and airtightness or the glazing type. The analyses also included the calculation of heat losses reduction achieved thanks to the solar spaces.
\end{abstract}

\section{Introduction}

Greenhouse systems allow the conversion of solar radiation into heat energy due to the glazed usable area adjacent to the building and separated from the interior by a heat accumulating partition. The sunspace is simultaneously a kind of solar collector and a thermal buffer that combines the function of gaining solar energy with the heat protection of the residential part of the building [1]. The solar space itself is not heated and may be subject to significant temperature fluctuations which is a restriction to its use for utility purposes. The conditions in this area are dependent to a greater extent on the external environment than the conditions in the heated or cooled residential area $[2,3]$.

Greenhouse systems have many advantages as they combine heat and acoustic protection of the interiors with great architectural attraction. Sunspaces provided by the glazed balconies or loggias may be constructed both in the already existing buildings and the newly erected ones. The elasticity is particularly important from the point of view of a chance to obtain a fast and relatively cheap improvement of the energetic standard of many existing objects $[4,5]$.

Although passive systems have been used for many years and they function well in a lot of buildings, in most objects in Poland it is hard to perceive them as consciously designed. The basic parameters concerned with the efficiency of the system such as the ability of solar energy transmission or the heat capacity of the object's casing are usually selected intuitively by the designers without a detailed estimation of the efficiency of the offered solutions. Such a state of affairs may lead to numerous mistakes that do not allow to take a full advantage of the passive systems or cause overheating of the rooms and temporary or prolonged discomfort for the users [6]. The above mentioned problems are the reasons of the Author's interest in the subject and taking up the research described below which is a part of more comprehensive analyses comprising monitoring and dynamic simulations of flats with glazed balconies.

\section{Research methodology}

From July 2017 to September 2018 temperatures were registered in flats with encased balconies located in multi-apartment blocks of various types of construction. All balconies were encased individually by the inhabitants, first of all for utility and safety reasons - the objective was to obtain additional space separated from the external environment, to increase the security from burglary or from the bird-intruders. During the research temperature was monitored by iButton temperature sensors DS1922L with enhanced memory (Fig. 1). The data reading was done with the use of the interface MP00206 connected to the computer with a USB cable.

Sensors are characterised with the following parameters:

- measurement range: from $-40^{\circ} \mathrm{C}$ to $+85^{\circ} \mathrm{C}$

- precision of measurement: $\pm 0.5^{\circ} \mathrm{C}$ within the range from $-10^{\circ} \mathrm{C}$ to $+65^{\circ} \mathrm{C}$

Corresponding author: m.grudzinska@ pollub.pl 
- resolution of measurement: $0.5^{\circ} \mathrm{C}$ or $0.0625^{\circ} \mathrm{C}(8$ or 11 bits)

- memory capacity: 8192 measurements for 8-bit readings or 4096 measurements for 16-bit readings interval of readings: from 1 second to 273 hours.

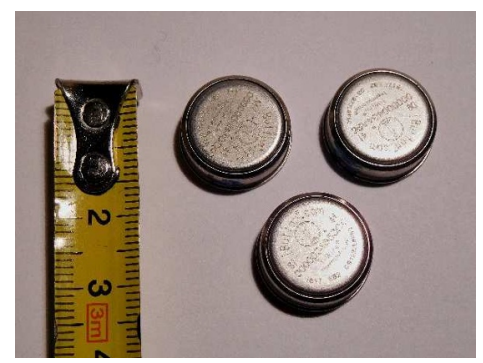

Fig. 1. The iButton sensors.

Temperature registration was done on the balconies and in the chosen residential areas (adjacent to the balconies). Number of the sensors used and their location is given in the Table 1 . Sensors in the rooms and kitchens were situated far from the windows and in the non-sunlit spots. Temperature loggers at the balconies were situated on the lintel walls, or at the bottom side of the balcony slab (flat no 5). The selected places were constantly shaded apart from the balcony of the flat no 3 . Due to its western exposition it was not possible to settle the space which would not be sunlit for a certain time. That is why it was necessary to neglect certain measurement data in the further analyses (about $18 \%$ of the overall number of observations).

Climatic data taken into account in the analyses were obtained from the stations of the Polish Institute of Meteorology and Water Management (IMGW - Instytut Meteorologii i Gospodarki Wodnej) in Lublin and Zamość (identifiers: 351220495 and 350230595). The Lublin-Radawiec station is a hydrologicalmeteorological station situated to the South - West of Lublin ( $\left.51^{\circ} 13^{\prime \prime} \mathrm{N}, 22^{\circ} 24^{\prime} \mathrm{W}\right)$ at the height of 238 metres above sea level at the distance of 10 to $14 \mathrm{~km}$ from the monitored buildings. The station in Zamość is an automatic synoptic station situated on the southern outskirts of the town $\left(50^{\circ} 42^{\prime} \mathrm{N}, 23^{\circ} 15^{\prime} \mathrm{E}\right)$ at the height of 212 metres above sea level, about $2,5 \mathrm{~km}$ from the monitored buildings. The data were obtained from the database available by means of the ICT system at the address: http://dane.imgw.pl. They comprised, among others, information concerning temperature of the air outside, relative humidity, atmospheric pressure, wind direction and velocity provided at hour intervals.

\section{Description of buildings}

The earliest research was carried out from 03.07.2017 to 27.03.2018 in Zamość at the area of the housing cooperative by the name of J. Zamoyski in 11-storey buildings of prefabricated construction (flats no 1 and 2). The buildings were constructed according to the technology Wk-70 of reinforced concrete layer prefabricates insulated with EPS boards $12 \mathrm{~cm}$ thick. The structural system of the buildings was diagonal, the height of a storey was $2.8 \mathrm{~m}$. The outer walls were additionally insulated with graphite EPS $10 \mathrm{~cm}$ thick according to the ETICS system (flat no 1, Fig. 2) or mineral wool $8 \mathrm{~cm}$ thick, installed on a wooden grid and covered with trapezoidal metal sheets (flat no 2, Fig. 3).

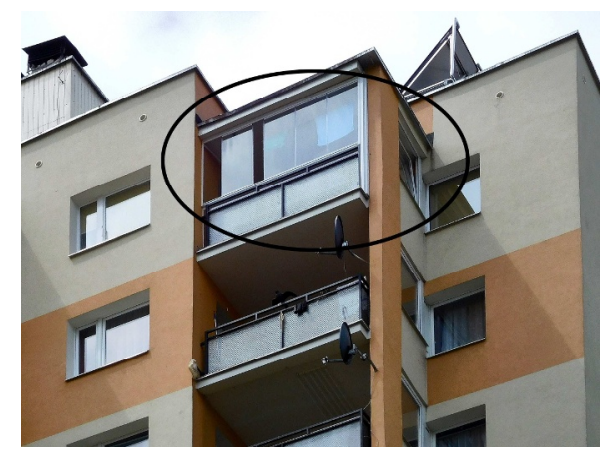

Fig. 2. Zamość, flat no 1.

Thermal transmittance coefficients of the outer partitions after thermal modernisation were respectively $0.19 \mathrm{~W} / \mathrm{m}^{2} \mathrm{~K}$ and $0.21 \mathrm{~W} / \mathrm{m}^{2} \mathrm{~K}$. Ventilated flat roofs in both buildings were insulated with wool pellets $18 \div 20$ $\mathrm{cm}$ thick.

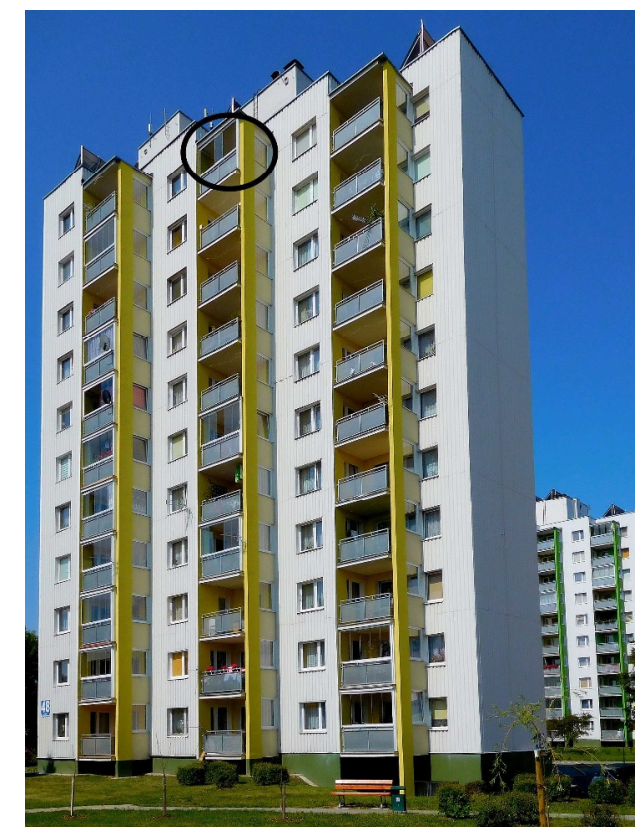

Fig. 3. Zamość, flat no 2.

Encasement of the balconies was accomplished on the basis of a design made on behalf of the housing cooperative in 2011. The frameless construction system was used for the casing, without vertical frames between the panes. The glass panels are made of toughened safety glass $10 \mathrm{~mm}$ thick without spectrally selective coating. Silicon gaskets are installed in the guide profiles and between the panes. At the bottom part of the casing a polycarbonate chamber plate $6 \mathrm{~mm}$ thick is fixed to the earlier existing railing. A side wall of the balcony is covered with an insulated multi-layered board $12 \mathrm{~cm}$ thick up to the height of $1.1 \mathrm{~m}$ and insulated with EPS board $4 \mathrm{~cm}$ thick. Balconies in both flats face South-East and they are situated at the $11^{\text {th }}$ storey. 
During a similar period of time (from 13.07.2017 to 11.03.2018) temperature was registered in a flat no 3 , located in Lublin. The building itself is a terraced house, consisting of 6 segments, 5 storeys each, gross height of each storey equal to $2.9 \mathrm{~m}$. The highest storey is a habitable attic with a saddle roof. The construction system is diagonal, the load-bearing walls and the ceilings are made of the hollow core slabs of the "Żerań" type and the curtain walling of aerated concrete $24 \mathrm{~cm}$ thick. The outer walls were insulated with $10 \mathrm{~cm}$ thick EPS boards in the ETICS system. Thermal transmittance coefficients were $0.35 \mathrm{~W} / \mathrm{m}^{2} \mathrm{~K}$ and $0.26 \mathrm{~W} / \mathrm{m}^{2} \mathrm{~K}$ respectively for the load-bearing walls and curtain walls. The encasement of balconies was also accomplished in the frameless system, of the ordinary $10 \mathrm{~mm}$ thick toughened safety glass set in the vertical aluminium guide rails. Clearance between the leaves was about 17 $\mathrm{mm}$, below the rail a polycarbonate chamber plate was fixed. The balcony faces North-West (Fig. 4).

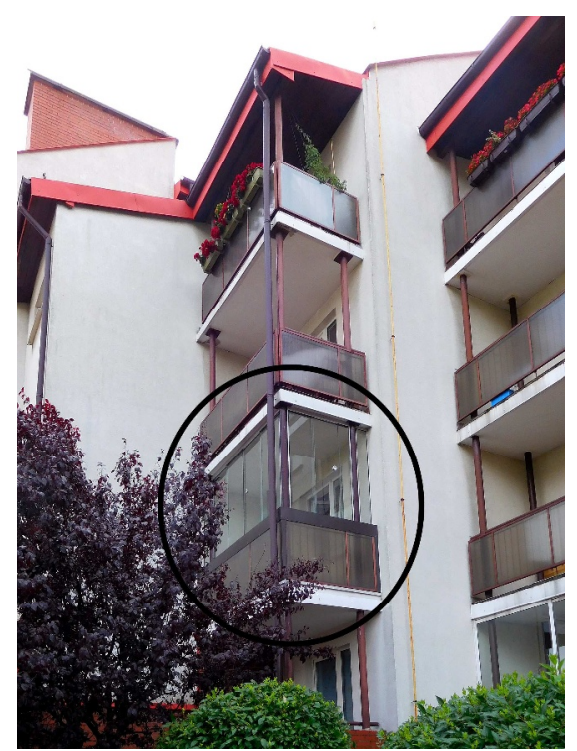

Fig. 4. Lublin, flat no 3.

Table 1. Monitored apartments - basic information.

\begin{tabular}{|c|c|c|c|c|c|c|c|c|}
\hline No & Location & $\begin{array}{c}\text { Area of the } \\
\text { flat and the } \\
\text { balcony }\end{array}$ & $\begin{array}{l}\text { Monitoring } \\
\text { period }\end{array}$ & $\begin{array}{l}\text { Number of } \\
\text { inhabitants }\end{array}$ & $\begin{array}{c}\text { Average } \\
\text { internal } \\
\text { gains } \\
\end{array}$ & $\begin{array}{c}\text { Type of the } \\
\text { balcony's glazing }\end{array}$ & $\begin{array}{c}\text { Balcony's } \\
\text { orientation }\end{array}$ & $\begin{array}{c}\text { Number and } \\
\text { location of the } \\
\text { sensors } \\
\end{array}$ \\
\hline 1. & $\begin{array}{l}\text { Zamość, st. } \\
\text { Wyszyńskiego } \\
42,11^{\text {th }} \text { floor }\end{array}$ & $\begin{array}{c}62.34 \mathrm{~m}^{2} \\
6.36 \mathrm{~m}^{2}\end{array}$ & $\begin{array}{c}03.07 .2017 \\
\div \\
27.03 .2018\end{array}$ & 5 & $7.0 \mathrm{~W} / \mathrm{m}^{2}$ & $\begin{array}{l}\text { Frameless, single } \\
\text { uncoated glazing }\end{array}$ & SE & $\begin{array}{c}4 \\
(B+K+2 x R)\end{array}$ \\
\hline 2. & $\begin{array}{l}\text { Zamość, st. } \\
\text { Wyszyńskiego } \\
48,11^{\text {th }} \text { floor }\end{array}$ & $\begin{array}{c}35.35 \mathrm{~m}^{2} \\
6.36 \mathrm{~m}^{2}\end{array}$ & $\begin{array}{c}03.07 .2017 \\
\div \\
27.03 .2018\end{array}$ & 1 & $5.6 \mathrm{~W} / \mathrm{m}^{2}$ & $\begin{array}{l}\text { Frameless, single } \\
\text { uncoated glazing }\end{array}$ & SE & $\begin{array}{c}3 \\
(\mathrm{~B}+\mathrm{K}+\mathrm{R})\end{array}$ \\
\hline 3. & $\begin{array}{l}\text { Lublin, st. } \\
\text { Baśniowa 9, } 2^{\text {nd }} \\
\text { floor }\end{array}$ & $\begin{array}{c}55.60 \mathrm{~m}^{2} \\
5.01 \mathrm{~m}^{2}\end{array}$ & $\begin{array}{c}13.07 .2017 \\
\div \\
11.03 .2018\end{array}$ & 1 & $3.1 \mathrm{~W} / \mathrm{m}^{2}$ & $\begin{array}{l}\text { Frameless, single } \\
\text { uncoated glazing }\end{array}$ & NW & $\begin{array}{c}2 \\
(B+R)\end{array}$ \\
\hline 4. & $\begin{array}{l}\text { Lublin, st. } \\
\text { Szmaragdowa } \\
34,1^{\text {st }} \text { floor }\end{array}$ & $\begin{array}{l}62.50 \mathrm{~m}^{2} \\
4.20 \mathrm{~m}^{2}\end{array}$ & $\begin{array}{c}02.01 .2018 \\
\div \\
25.09 .2018\end{array}$ & 3 & $6.8 \mathrm{~W} / \mathrm{m}^{2}$ & $\begin{array}{l}\text { PVC profiles, } \\
\text { double glazing }\end{array}$ & $\mathrm{E}$ & $\begin{array}{c}2 \\
(B+R)\end{array}$ \\
\hline
\end{tabular}

B - Balcony, K - Kitchen, R - Room

At the beginning of 2018 two further flats were joined to the research (no 4 and 5), both accomplished in the prefabricated technology. The building no 4 is a twelve-storey tower block, with full basement and a ventilated flat roof. The load-bearing construction was performed in the W-70 technology and the $37 \mathrm{~cm}$ thick curtain walls were made of aerated concrete of the type 600 (Fig. 5). The construction system is mixed, transverse-longitudinal, the gross height of one storey is $2.8 \mathrm{~m}$. The outer walls were insulated by means of the ETICS method using EPS and $10 \mathrm{~cm}$ thick facade mineral wool. Thermal transmittance coefficients after thermal modernisation were $0.28 \mathrm{~W} / \mathrm{m}^{2} \mathrm{~K}$ and 0.25 $\mathrm{W} / \mathrm{m}^{2} \mathrm{~K}$ respectively for the load-bearing walls and for curtain walls.

Casing of the balcony in the flat no 4 was made with the use of windows with one-chamber glazing set in the PVC profiles. The wall under the window is a reinforced concrete slab and a polycarbonate chamber plate fixed inside the balcony at the level of the primary openwork balustrade.

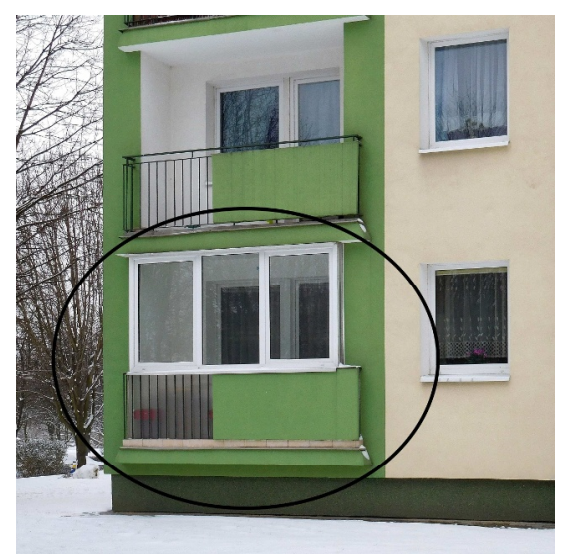

Fig. 5. Lublin, flat no 4. 
The building no 5 is a two-staircase, eleven-storey building, performed in the technology of Żerań bricks in the diagonal construction system (Fig. 6).

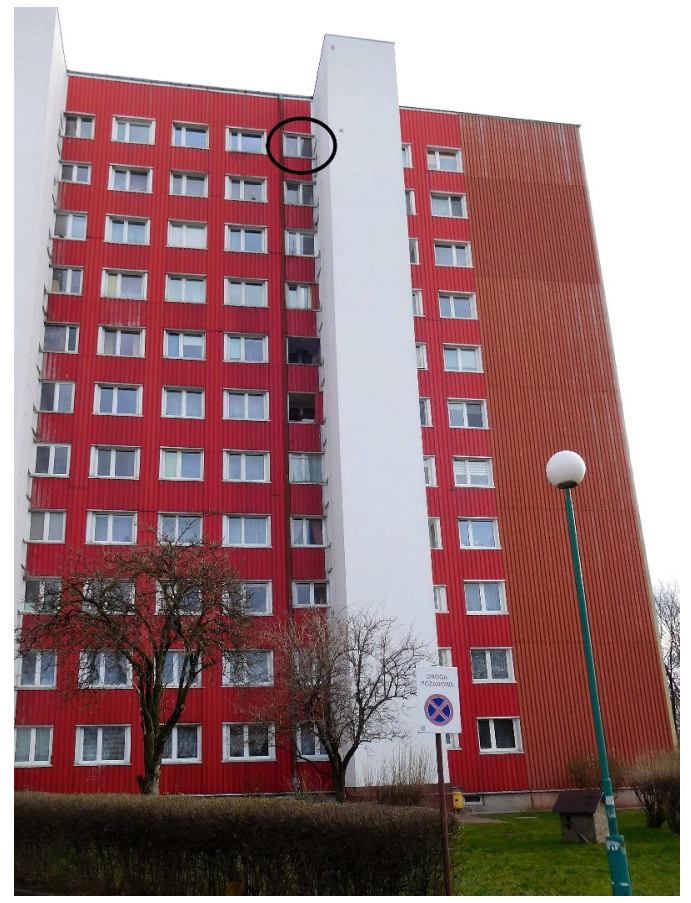

Fig. 6. Lublin, flat no 5 (loggia located next to the elevator shaft).

The $24 \mathrm{~cm}$ thick curtain walls are made of aerated concrete. Over the last storey there is partly a ventilated flat roof and partly - the utility rooms covered with a full flat roof. The gross height of a storey is $2.8 \mathrm{~m}$. The outer walls were insulated using the $6 \mathrm{~cm}$ thick mineral wool and finishing with trapezoidal metal sheets. Thermal transmittance coefficients after thermal modernisation were $0.53 \mathrm{~W} / \mathrm{m}^{2} \mathrm{~K}$ and $0.35 \mathrm{~W} / \mathrm{m}^{2} \mathrm{~K}$ respectively for the load-bearing walls and the curtain walls. In the flat no 5 the casing of the loggia is also provided by the windows with PVC profiles with a one-chamber glazing and the wall under the window is made of brick and mortar. There are problems with fungi in the flat, also upon the balcony casing which testifies to an insufficient air exchange.

All the flats have a functioning gravitational ventilation dependent upon the atmospheric conditions and the tightness degree of the casing.

\section{Monitoring results}

The basic data obtained on the basis of monitoring were put together in tables $2 \div 6$. These are the monthly average temperatures of the sunlit space and the habitable rooms adjacent to the balcony, supplemented with the average temperatures of the air outside taken from the IMGW database. If the monthly data were not complete (e.g. because of the time of measurement or elimination of the results from the time of direct insolation of the sensor) the averaged values come from a shorter period of time.

Table 2. Flat no 1 - monitoring results.

\begin{tabular}{|c|c|c|c|c|c|c|}
\hline Year & Month & $\begin{array}{c}\text { Average } \\
\text { external } \\
\text { temperature } \\
\\
{\left[{ }^{\circ} \mathrm{C}\right]}\end{array}$ & $\begin{array}{c}\text { Average } \\
\text { temperature } \\
\text { in the } \\
\text { sunspace } \\
{\left[{ }^{\circ} \mathrm{C}\right]}\end{array}$ & $\begin{array}{c}\text { Average } \\
\text { temperature } \\
\text { in the flat } \\
{\left[{ }^{\circ} \mathrm{C}\right]}\end{array}$ & $\begin{array}{c}\text { Correlation } \\
\text { between sunspace } \\
\text { and ext. } \\
\text { temperature } \\
{[-]}\end{array}$ & $\begin{array}{c}\text { Temperature } \\
\text { correction } \\
\text { factor } b_{\text {tr }} \\
{[-]}\end{array}$ \\
\hline \multirow[t]{6}{*}{2017} & VII* & 18.5 & 26.3 & 26.6 & 0.718 & 0.037 \\
\hline & VIII & 19.7 & 26.7 & 27.2 & 0.854 & 0.073 \\
\hline & IX & 13.7 & 18.9 & 23.7 & 0.798 & 0.484 \\
\hline & $X$ & 9.2 & 14.9 & 24.0 & 0.836 & 0.611 \\
\hline & XI & 3.8 & 10.1 & 24.1 & 0.753 & 0.688 \\
\hline & XII & 1.8 & 8.4 & 24.4 & 0.689 & 0.708 \\
\hline \multirow[t]{3}{*}{2018} & I & -0.2 & 6.9 & 24.1 & 0.817 & 0.709 \\
\hline & II & -4.4 & 6.0 & 24.6 & 0.641 & 0.640 \\
\hline & III* & -1.9 & 9.4 & 24.3 & 0.789 & 0.569 \\
\hline
\end{tabular}

* incomplete data

Table 3. Flat no 2 - monitoring results.

\begin{tabular}{|c|c|c|c|c|c|c|}
\hline Year & Month & $\begin{array}{c}\text { Average } \\
\text { external } \\
\text { temperature }\end{array}$ & $\begin{array}{c}\text { Average } \\
\text { temperature } \\
\text { in the } \\
\text { sunspace } \\
{\left[{ }^{{ }} \mathbf{C}\right]}\end{array}$ & $\begin{array}{c}\text { Average } \\
\text { temperature } \\
\text { in the flat } \\
{\left[{ }^{\mathbf{}} \mathbf{C}\right]}\end{array}$ & $\begin{array}{c}\text { Correlation } \\
\text { between sunspace } \\
\text { and ext. } \\
\text { temperature } \\
{\left[{ }^{\mathbf{}} \mathbf{C}\right]}\end{array}$ & $\begin{array}{c}\text { Temperature } \\
\text { correction } \\
\text { factor } \mathbf{b}_{\text {tr }}\end{array}$ \\
\hline 2017 & VII $^{*}$ & 18.5 & 24.3 & 24.6 & 0.796 & 0.054 \\
\hline & VIII & 19.7 & 25.5 & 25.8 & 0.861 & 0.055 \\
\hline & IX & 13.7 & 17.0 & 20.6 & 0.836 & 0.520 \\
\hline & $\mathrm{X}$ & 9.2 & 13.4 & 20.6 & 0.827 & 0.625 \\
\hline
\end{tabular}




\begin{tabular}{|c|c|c|c|c|c|c|}
\hline & XI & 3.8 & 10.3 & 19.8 & 0.293 & 0.590 \\
\hline & XII & 1.8 & 8.7 & 19.8 & 0.153 & 0.616 \\
\hline 2018 & I & -0.2 & 7.8 & 19.4 & 0.560 & 0.595 \\
\hline & II & -4.4 & 7.8 & 19.8 & 0.245 & 0.496 \\
\hline & III $^{*}$ & -1.9 & 11.8 & 20.7 & 0.499 & 0.396 \\
\hline
\end{tabular}

* incomplete data

Table 4. Flat no 3 - monitoring results.

\begin{tabular}{|c|c|c|c|c|c|c|}
\hline Year & Month & $\begin{array}{c}\text { Average } \\
\text { external } \\
\text { temperature } \\
{\left[{ }^{\circ} \mathbf{C}\right]}\end{array}$ & $\begin{array}{c}\text { Average } \\
\text { temperature } \\
\text { in the } \\
\text { sunspace } \\
{\left[{ }^{\circ} \mathbf{C}\right]}\end{array}$ & $\begin{array}{c}\text { Average } \\
\text { temperature } \\
\text { in the flat }\end{array}$ & $\begin{array}{c}\text { Correlation } \\
\text { between sunspace } \\
\text { and ext. } \\
\text { temperature } \\
{\left[{ }^{\circ} \mathbf{C}\right]}\end{array}$ & $\begin{array}{c}\text { Temperature } \\
\text { correction } \\
\text { factor } \mathbf{b}_{\text {tr }}\end{array}$ \\
\hline 2017 & $\mathrm{VII}^{*}$ & 18.2 & 22.0 & 23.8 & 0.648 & 0.323 \\
\hline & $\mathrm{VIII}^{*}$ & 18.7 & 21.9 & 24.7 & 0.803 & 0.462 \\
\hline & $\mathrm{IX}^{*}$ & 13.1 & 15.3 & 21.0 & 0.801 & 0.730 \\
\hline & $\mathrm{X}^{*}$ & 8.6 & 10.5 & 21.3 & 0.876 & 0.856 \\
\hline & $\mathrm{XI}^{*}$ & 3.3 & 5.3 & 21.3 & 0.913 & 0.891 \\
\hline & $\mathrm{XII}^{*}$ & 1.6 & 3.4 & 21.3 & 0.888 & 0.910 \\
\hline & $\mathrm{I}^{*}$ & -0.2 & 2.1 & 21.3 & 0.912 & 0.890 \\
\hline & $\mathrm{II}^{*}$ & -3.8 & -0.1 & 21.3 & 0.938 & 0.852 \\
\hline
\end{tabular}

* incomplete data

Table 5. Flat no 4 - monitoring results.

\begin{tabular}{|c|c|c|c|c|c|c|}
\hline Year & Month & $\begin{array}{c}\text { Average } \\
\text { external } \\
\text { temperature }\end{array}$ & $\begin{array}{c}\text { Average } \\
\text { temperature } \\
\text { in the } \\
\text { sunspace } \\
{\left[{ }^{\mathbf{}} \mathbf{C}\right]}\end{array}$ & $\begin{array}{c}\text { Average } \\
\text { temperature } \\
\text { in the flat } \\
{\left[{ }^{\mathbf{}} \mathbf{C}\right]}\end{array}$ & $\begin{array}{c}\text { Correlation } \\
\text { between sunspace } \\
\text { and ext. } \\
\text { temperature } \\
{[-]}\end{array}$ & $\begin{array}{c}\text { Temperature } \\
\text { correction } \\
\text { factor } \mathbf{b}_{\text {tr }}\end{array}$ \\
\hline 2018 & I $^{*}$ & -0.5 & 4.9 & 21.6 & 0.906 & 0.755 \\
\hline & II & -4.1 & 5.0 & 21.9 & 0.744 & 0.651 \\
\hline & III & -0.5 & 7.5 & 21.8 & 0.868 & 0.640 \\
\hline & IV & 13.0 & 18.0 & 21.6 & 0.855 & 0.422 \\
\hline & V & 16.7 & 20.2 & 21.5 & 0.813 & 0.283 \\
\hline & VI & 18.2 & 22.0 & 23.0 & 0.812 & 0.206 \\
\hline & VII & 19.9 & 23.0 & 23.4 & 0.798 & 0.120 \\
\hline & VIII & 20.2 & 24.0 & 24.4 & 0.777 & 0.102 \\
\hline & IX & 16.5 & 19.4 & 21.8 & 0.814 & 0.453 \\
\hline
\end{tabular}

* incomplete data

Table 6. Flat no 5 - monitoring results.

\begin{tabular}{|c|c|c|c|c|c|c|}
\hline Year & Month & $\begin{array}{c}\text { Average } \\
\text { external } \\
\text { temperature }\end{array}$ & $\begin{array}{c}\text { Average } \\
\text { temperature } \\
\text { in the } \\
\text { sunspace } \\
{\left[{ }^{\mathbf{}} \mathbf{C}\right]}\end{array}$ & $\begin{array}{c}\text { Average } \\
\text { temperature } \\
\text { in the flat } \\
{\left[{ }^{\circ} \mathbf{C}\right]}\end{array}$ & $\begin{array}{c}\text { Correlation } \\
\text { between sunspace } \\
\text { and ext. } \\
\text { temperature } \\
{[-]}\end{array}$ & $\begin{array}{c}\text { Temperature } \\
\text { correction } \\
\text { factor } \mathbf{b}_{\text {tr }}\end{array}$ \\
\hline 2018 & I $^{*}$ & -0.7 & 14.8 & 23.4 & 0.493 & 0.357 \\
\hline & II & -4.1 & 14.5 & 24.2 & 0.493 & 0.342 \\
\hline & III & -0.5 & 16.8 & 24.5 & 0.775 & 0.309 \\
\hline & IV & 13.0 & 23.5 & 25.9 & 0.483 & 0.188 \\
\hline & V & 16.7 & 26.4 & 26.6 & 0.376 & 0.023 \\
\hline & VI & 18.2 & 28.2 & 28.2 & 0.367 & 0.003 \\
\hline & VII & 19.9 & 27.2 & 27.5 & 0.498 & 0.032 \\
\hline & VIII & 20.2 & 28.9 & 29.2 & 0.458 & 0.025 \\
\hline & IX & 16.1 & 25.1 & 25.7 & 0.576 & 0.055 \\
\hline
\end{tabular}

\footnotetext{
* incomplete data
} 
Air temperature in the sunspace is usually higher than the temperature of the air outside $(91.6 \% \div 98.5 \%$ of the time of the measurement, Fig. 7), moreover, the differences are not stable during the year. The months when the temperature increase is the biggest are January, February and March, i.e. the periods of time with the lowest average temperatures of the external air. The highest temperature increase being $7.3^{\circ} \mathrm{C}$ to $18.6^{\circ} \mathrm{C}$ on average was observed in the flat no 5 . The loggia is quite tightly encased there (the closed double-pane windows in the PVC profiles and a masonry wall under the window) and the inhabitants sometimes leave the door open between the loggia and the adjacent room. The lowest temperature differences occur in case of the balconies with a high degree of air infiltration - these are the flats no 3 (casing with the clearance between the panes about $17 \mathrm{~mm}$ ) and 4 (constantly ventilated by leaving the windows open).

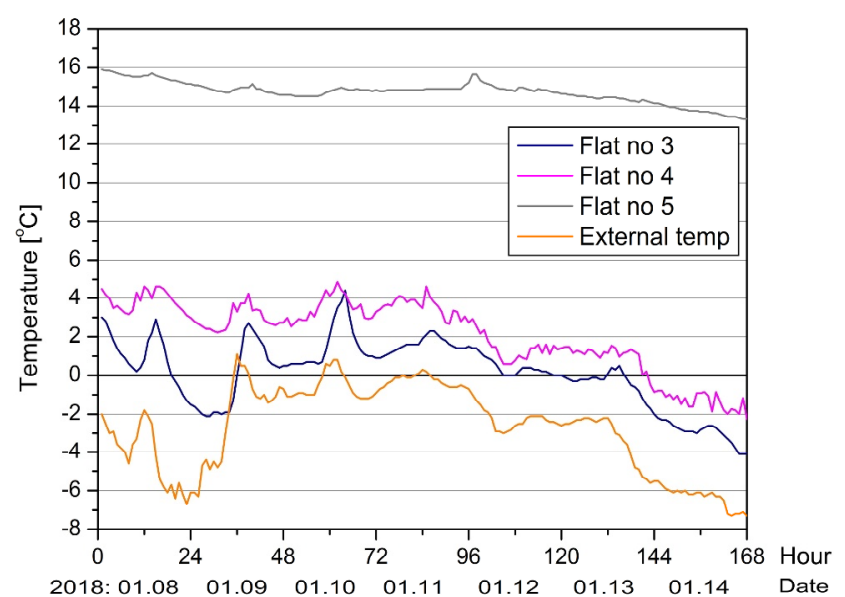

Fig. 7. Balconies' temperature compared with external temperature.

The periods of time when the temperature is lower than that of the surroundings are relatively short $(0.8 \%$ to $8.4 \%$ of the measurement time) and the time of their occurrence is related to the daily weather cycle and the thermal capacity of the casing. At the balconies of the lightest construction (encasement made of polycarbonate plates + frequent ventilation, flats no 3 and 4) temperature decrease below that of the surroundings occurred respectively between 7 a.m. and 12 noon and between 6 a.m. and 9 a.m. during the temperature rise after a colder night. At the balconies with a heavier encasement with masonry walls under the windows or the side walls (flats no 1,2 and 5) the temporary falls of temperature occurred respectively between 12 noon and 3 p.m. and in the second flat - between 10 a.m. and 3 p.m.. It is concerned with a bigger thermal capacity of the casing and slower heating and also with a temporary shading of the balconies relatively by the elevator shaft or a masonry side wall. The differences usually did not exceed $5^{\circ} \mathrm{C}$.

Air temperature in the sunspaces is quite well correlated with the temperature of the air outside. The biggest interdependence of the temperature course occurred at the balcony of the flat no 3 with the least tight and weakly isolated encasement and also at the balcony of the flat no 4 , where one of the windows was constantly open. It is certainly concerned with the possibility of influx of the air from outside and a more intense heat exchange with the surroundings. The balcony in the flat no 5 is characterised by the lowest correlation coefficient, as its encasement is well isolated and airtight and the temperature may be influenced by the inflow of the air from the heated living space.

A certain way of estimation of influence of the encased balconies upon the height of heat losses from the habitable areas may be the temperature correction factor $b_{\text {tr }}$ defined by the standard [7] as:

$$
b_{t r}=\left(\theta_{i}-\theta_{b}\right) /\left(\theta_{i}-\theta_{e}\right)
$$

where:

$\theta_{\mathrm{i}}-$ air temperature in a heated room $\left[{ }^{\circ} \mathrm{C}\right]$

$\theta_{\mathrm{b}}$ - air temperature at the balcony $\left[{ }^{\circ} \mathrm{C}\right]$

$\theta_{\mathrm{e}}-$ outside air temperature $\left[{ }^{\circ} \mathrm{C}\right]$.

Temperature measurement during the heating season has become the basis for determining monthly average values of the coefficient $b_{\text {tr }}$ (Fig. 8).

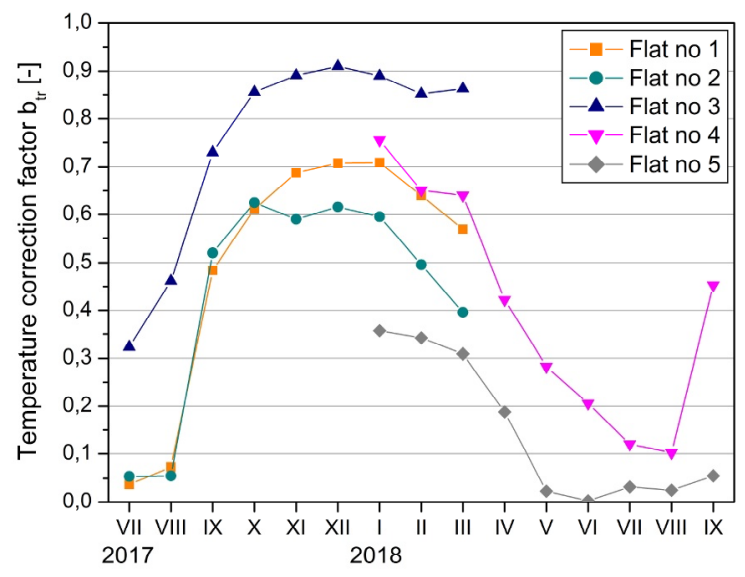

Fig. 8. Temperature correction factor.

In all flats the highest temperature correction factors were observed during the autumn and winter months (November, December and January in the flats where measurements were made during the full heating season and January, February, March in the flats where measurements started in January 2018). The lowest coefficients were obtained in the spring and summer season.

The smallest influence upon the restriction of heat losses during the heating season was observed at the balcony with light encasement and a significant rate of air infiltration (flat no 3), the changes here were within the range of 0.730 (September) to 0.910 (December). In spite of small tightness and low isolation qualities of the casing the influence of the sunlit area is visible, although rather insignificant.

The following constructions as to effectiveness are the ones at the flat no $1\left(b_{\text {tr }}\right.$ from 0.484 in September to 0.709 in January) and no 4 ( $b_{\text {tr }}$ from 0.283 in May to 0.755 in January). During two weeks in February (from $15^{\text {th }}$ to $\left.28^{\text {th }}\right)$ at the request of the author the window in

*Corresponding author: m.grudzinska@ @ollub.pl 
the balcony of the flat no 4 was closed and the average temperature correction coefficient was then 0.588 , i.e. it was lower than during the rest of the winter period. Usually the window is opened most of the time because the inhabitants use the balcony as a smoking zone.

In the flats no 1 and 2 , in spite of the same construction and direction of the balconies the coefficients $b_{t r}$ differ by $1 \%$ (October) to almost $40 \%$ (March). It is probably because the areas are exploited in a different way but as no detailed registration of the frequency of opening the windows was made, it is difficult to estimate clearly which factors play a decisive role in this case. In the flat no 2 internal temperature is on average lower by $3.5^{\circ} \mathrm{C}$ than in the flat no 1 , due to lower internal gains and inhabitant's preferences as to the heating intensity. These may have some impact on the differences in the values of the temperature correction factor, as well as the smaller area of the flat no 2.

In case of an encased loggia in the flat no 5 the temperature correction factor during the heating season was changing within the range of 0.023 (May) to 0.357 (January) reaching the lowest values among the monitored flats. The highest air temperatures were also registered here in the sunspace. They were the result of tight encasement and small surface of the external partitions heat - loggia has only one wall that touches the outer air. The inhabitants sometimes leave the door between the living room and the loggia open which also causes an increase of temperature within its area.

In June, July and August temperature correction factors are much smaller than during the heating season. In the flats no 1, 2 and 3 they are close to zero as a result of very frequent opening of windows of the balcony casing and the door to the habitable rooms. In the other cases the $b_{\text {tr }}$ factors are bigger $(0.10 \div 0.21$ - flat no 4 and $0.32 \div 0.46$ - flat no 5 ).

\section{Heat losses reduction from the habitable rooms}

In the monitored flats the heat losses through the casing were calculated during the months included in the heating season (Table 7). Methodology of the calculations was accepted according to [8], using the experimentally determined temperature reduction coefficients $b_{\text {tr }}$. Heat losses coefficient $\mathrm{H}_{\mathrm{tr}}$ between the heated room and the non-heated area was determined with the use of the coefficient $b_{\text {tr }}$ according to [8]:

$$
H_{t r}=b_{t r} \cdot H_{i b}
$$

where:

$\mathrm{H}_{\mathrm{ib}}$ - heat losses coefficient between the heated room and the non-heated one $[\mathrm{W} / \mathrm{K}]$.

Table 7. Heat losses reduction in the monitored flats.

\begin{tabular}{|c|c|c|c|c|c|c|c|c|c|c|c|}
\hline \multirow{3}{*}{ Flat no } & \multicolumn{11}{|c|}{ Heat losses reduction [\%] } \\
\hline & \multicolumn{4}{|c|}{2017} & \multicolumn{6}{|c|}{2018} & \multirow{2}{*}{$\begin{array}{c}\text { In the heating } \\
\text { season }\end{array}$} \\
\hline & IX & $\mathbf{X}$ & $\mathbf{X I}$ & XII & I & II & III & IV & $\mathbf{V}$ & IX & \\
\hline 1 & 15.6 & 11.7 & 9.4 & 8.8 & 8.8 & 10.9 & 13.0 & - & - & - & 10.7 \\
\hline 2 & 27.9 & 21.8 & 23.8 & 22.3 & 23.6 & 29.3 & 35.1 & - & - & - & 26.6 \\
\hline 3 & 7.9 & 4.2 & 3.2 & 2.6 & 3.2 & 4.3 & 4.0 & - & - & - & 3.8 \\
\hline 4 & - & - & - & - & 3.6 & 5.2 & 5.3 & 8.6 & 10.6 & 8.1 & 5.6 \\
\hline 5 & - & - & - & - & 11.8 & 12.0 & 12.6 & 14.9 & 17.9 & 17.3 & 13.4 \\
\hline
\end{tabular}

In each of the monitored flats due to the encasement of the balconies a reduction of heat losses through the casing was obtained being on average from $3.8 \%$ (flat no 3) to $26.6 \%$ (flat no 2). Balconies with the least tight casing (due to the crevices between the panes or constant ventilation) proved to be the least efficient buffer zone and the average heat losses reduction during the heating season was maximum $5.6 \%$. In case of the flat no 4 a significant influence upon the little efficiency of the greenhouse area was also exerted by the serious heat losses through the outer walls and the floor on the ground over the non-heated cellars. In the smaller flats the glazed buffer area gave significantly better effects i.e. in the flats no 5 and 2 where the average heat loss reduction was respectively $13.4 \%$ and $26.6 \%$ in spite of the fact that both flats were situated at the highest floor. In flats no 1 and 2 the encasement of the balconies is the same, but its efficiency has proved much less in case of the flat of a bigger surface area (no 1), where the heat losses reduction was $10.7 \%$ on average.
The results proved to be quite varied during the heating season. Heat losses through the encasement were reduced to the greatest extent in spring and autumn, i.e. from March to May and in October. In November, December and January the percentage of heat losses reduction due to the encased balconies proved to be the smallest (Fig. 9). 


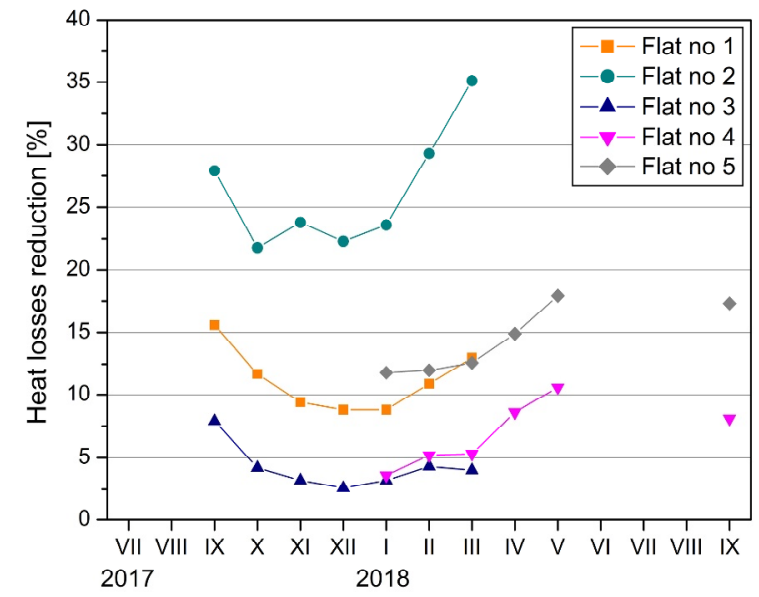

Fig. 9. Heat losses reduction.

\section{Summary}

Glazed balconies are attractive for the users and it is a relatively simple way to introduce the greenhouse system in the existing buildings as well as in the newly designed ones. In all the monitored flats during the heating season an increase of temperature was observed within the area of the balcony or loggia over the temperature of the outside environment which allowed the reduction of heat losses from the adjacent rooms.

Due to various types of construction and the tightness of the casing as well as the orientation of the balconies the efficiency of conversion of the solar radiation proved to be varied. Because of the financial limitations of the research not all of the factors influencing the passive sunspace systems performance could have been measured and analysed, namely the solar radiation and the wind speed at different levels above the ground. Therefore it is difficult to assess which of them play the most important role in in the described cases.

However, on the basis of the research it was possible to determine certain constant trends, i.e.:

- the highest value of the heat losses factor during the coldest months of the heating season and the smallest heat losses reduction during the time

- efficiency increase of the radiation conversion during the transitional periods (autumn and spring)

- quite a significant link between the passive system efficiency and the tightness of the casing of the sunlit area

- connection between the user's behaviour and the efficiency of the sunspace system.

At the further stage of the research analyses will be extended by the dynamic computer simulations of the monitored flats. The measurement data will be used to estimate the risk of overheating the flats in summer.

The work was financially supported by the Ministry of Science and Higher Education within the statutory research number FN14/ILT/2019 at the Lublin University of Technology.

\section{References}

1. J.D. Balcomb (ed.), Passive Solar Buildings (The Massachusetts Institute of Technology Press, Cambridge, Massachusetts 1992).

2. M. Wall, Climate and energy use in glazed spaces (Report TABK-96/1009, Lund University, Department of Building Science, Lund 1996).

3. A.G. Hestnes, S.R. Hastings, B. Saxhof, Solar Energy Houses: Strategies, Technologies, Examples (James \& James Science Publishers Ltd, London 1996).

4. A. Haller, E. Schweizer (ed), Solar renovation concepts and systems (International Energy Agency, Solar Heating and Cooling Programme, A Report of Task 20 Subtask F, November 1999).

5. C. Porteous, K. MacGregor, Solar architecture in cool climates (Earthscan Publishers, London 2005).

6. T. Kisilewicz, The influence of resistive, dynamic and spectra features of the building walls on the thermal balance of the low energy buildings (Cracow University of Technology, Monograph no 364, Cracow 2008).

7. ISO 13789 Thermal performance of buildings. Transmission and ventilation heat transfer coefficients. Calculation method (European Committee for Standardization, Brussels, 2008).

8. ISO 13790 Energy performance of buildings. Calculation of energy use for space heating and cooling (European Committee for Standardization, Brussels, 2009). 